\title{
M'Wanna M'Bella and the Four Dollar Whore
}

\section{J. U. Ribeiro}

We figure there's all kinds of whores in this particular place and we are both very happy about it because we never expected it. We sort of hoped there would be some whores in this part of town, but they kept telling us you can never find a whore on Monday. They're supposed to go to church and pray or go to the cemetery and put flowers on their relatives' graves and generally behave in a ladylike manner until Tuesday morning, when they all come out in the sun at nine o'clock and start acting up and making all kinds of gestures and they go on all day and all night like machines. We guess these here whores are in pretty bad shape financially speaking, and most of them look like it, but we're getting so drunk on cheap wine we don't give a damn about it. In fact, M'Wanna M'Bella is very excited, and he says he's gonna light a joint of this black stuff that he got. I'm gonna get hallucinations, he says, and hallucinations on tops of hallucinations. Like you look at one of them whores in those cheap colorful rags and you take a real big drag on the joint and you hold your breath. Then the old doll kinda falls apart, he says, in very colorful bits and you get a funny whine in your ears with a rhythm to it, so that the rags will go tweeng-tweeng. Have you ever tried it, he says. No, I say. I also say he'd better not light up the joint, on account of this here is a strange town and people are always objecting to your smoking anything but tobacco. I'm very surprised at M'Wanna M'Bella because he looks at me very seriously and agrees. I agree, he says, and we sit down at this table quite contented and happy and all smiles and niceties. M'Wanna M'Bella gets nice to me and I get nice to him. I say, please, sir, after you, sir, are you comfortable, sir. And he says, no, sir, I insist, sir, what will you have, sir. We keep on doing that for awhile like we're having a great deal of fun doing it, and finally I can't help burping and M'Wanna M'Bella pretends he's very upset and shakes his big head and puts his hand over his mouth like he says the women in his tribe do when they are embarrassed. Now these guys are watching us, at first without understanding and then laughing, but M'Wanna M'Bella doesn't like that people laugh at him, so he frowns very powerfully at these people and they all stop laughing, 
for M'Wanna M'Bella is a very big man and he impresses people, I suppose, especially people who don't know him well like I do. When these people stop laughing, M'Wanna M'Bella starts wiggling around with his hand on his mouth and he's carrying on like a woman actually. I think he wants these men to go on laughing again, so that he can pick a fight, and I seen M'Wanna M'Bella in a fight and I don't like the idea.

"M'Wanna M'Bella," I say, “don't go and pick a fight now."

"Pick a fight?" he says flashing his two hundred shiny teeth. "Pick a fight? Have you ever seen me fight ants?"

"No," I say. "I never seen that."

"All right," he says. "Have you ever seen me fight little old ladies?"

"No," I say. "I ain't ever seen you do that."

"And have you," he says very slowly, "ever seen me fight lizards?"

"No," I say and I begin to worry a little because I notice M'Wanna M'Bella is trying to pick a fight with these men. Maybe he thinks they can fight for fun, which I think they can't. But it's useless that I worry because M'Wanna M'Bella is at it already and there's no stopping him when he's like that. So I get to thinking of how we can get the hell out of here real fast if things start getting serious, but all of a sudden M'Wanna M'Bella puts his hand on my shoulder and says very softly:

"All I see here is ants, lizards and little old ladies, and I will not fight them. I fight whales and elephants and vultures, eh?"

"Yes," I say, and I'm very relieved he sits down and these men out there don't seem to mind his calling them lizards and ants and little old ladies.

We notice everybody else is having beer, so we order a few bottles of beer and M'Wanna M'Bella seems to have forgotten all about lizards and ants and little old ladies and elephants and the like, and the whores are now parading near a kind of a counter they have in the back of this place. I think I've never seen such a sorry looking group of whores for as long as I have lived, and I say that to M'Wanna M'Bella, who's greatly interested in them and can't take his eyes away from them. He says things in his language as if I understood it; it never occurs to him I don't understand it.

"Ako-fah ako-fah eh ako-fah," he sings and claps his hands. "This is not a group," he says, "this is several groups."

And in fact there's several rows of whores as I can see now, and they are separated by quality. That's what the little man in the hat says in very strange Portuguese. He says something like putas de diversas qualidades, putas para todos os gostos, he says, and I think he's a big liar or he's got a problem if he thinks there's putas for every taste here, because I think most of them are of very inferior quality indeed. As a matter of fact, I wouldn't want to consort with most of these putas, but M'Wanna M'Bella doesn't seem to be bothered by that. He seems to have a word of praise for every puta that comes forth. There's this little runt holding a card that says A Forty Dollar Puta in big red letters, and he seems to think she's really something. These forty dollar putas figure they are very classy dames, and they are separated from the rest of the whores by a very greasy 
cordon that the little man holds up tied to the other end of the counter. To this side of the cordon there's some five or six rows of whores, and they are all holding up their signs. I notice most of the whores have spots on their legs like they were sick or something, but M'Wanna M'Bella says to me, I wish I could get like twenty dollars for me to go to bed with somebody, and I had to agree there. These women, M'Wanna M'Bella says, they make a living like that and you couldn't possibly make a living like that. Most of them are great lays, M'Wanna M'Bella explains, although it's beyond me how he knows that considering this is a kind of a white world he's never seen before, not that I know anyway. Now, among all those whores there's one that looks quite bad, she really seems to be the worst one in the lot, and she's holding a sign that says A Four Dollar Puta, and she tries her best not to look too unhappy because she smiles all around her and shows her spotted little legs and seems to be very proud of her gold front tooth. The little man is leading them in a song that says we're all putas we're prostitutas ba-ba-bada-ba-ra-da-da and she makes the loudest noise of them all, she goes I'm a puuuuta, I'm a prostituuuuuta, and M'Wanna M'Bella says he's very happy to see such pride in one's calling. I think she's been a puta all her life, he says, and there's nothing she'd rather be than a puta, he says. I am told, M'Wanna M'Bella says, that you're supposed to bargain with those whores. Like one of them says, I'm a forty dollar puta, and you say very loud: Fifteen dollars and I'll take the whole kit and caboodle, and she'll say: Twenty-five dollars and that's it, and you say: Nineteen dollars and let's hear no more of it, and she takes her little old rags off and gives it to you. You gotta be a man of the world, M'Wanna M'Bella says. Hmmm, I say, for I never heard M'Wanna M'Bella speak like that. I didn't know he knew all those things. What you do to these whores, M'Wanna M'Bella says, is you sorta play a game with them, like you gotta take from them all they can give and the more you take from them the more they'll like you. I say, how come you know all them things, and he says very simply, I am a man of the world. I take it as very peculiar for M'Wanna M'Bella to say that, but I don't want to be contrary on account of he's so happy and he's a good man and is having fun. He's shaking his big head from one side to the other and looking at the whores, and he seems attracted to the woman who holds the four dollar sign. I like this, he says, people here do things for money and she seems to be the one that does the most things, because she's smart and she charges very little. I'll try to pull out, M'Wanna M'Bella says. I'll try to pull out everything from that woman, he says, because she's the smartest woman in this here white setup. She only charges four dollars, do you see that. I answer him, it's just a market thing for that woman to be charging four dollars, for you see she's the one with all the fat (oh, says M'Wanna M'Bella very delightedly, that fat) and all the spots on her legs (spots, says M'Wanna M'Bella, what's wrong with spots and who looks at spots when one is spearing a woman with his Mighty Rod, woosh! says M'Wanna M'Bella making clucking noises with his tongue) and she's probably got the clap or something (an injection, I get injection, says M'Wanna M'Bella). Besides, M'Wanna M'Bella doesn't know what a market situation is anyway. He insists this woman is the smartest woman of them all. First, he says, 
she charges the least among them. That gets her more business than anybody else. And for four dollars nobody expects her to work too hard, so she really doesn't have to make an effort. You see, M'Wanna M'Bella says triumphantly, you don't know a thing about the world.

So we hang around some more looking at those rows of whores and M'Wanna M'Bella is getting more and more interested in the four dollar whore and he asks me what he can do to have her real quick, because all the whores are being picked up from the counterlike thing and they are not even singing any more. Don't worry, I say, no one is going to pick up that four dollar whore, you can keep your shirt on. But M'Wanna M'Bella is very impatient and so he pulls me by the arm and leads me to the women, and now there's only two or three of them and they look like a very bad bunch of women indeed in a sad sort of way. They call you paizinho, paizinho, which means little daddy and I could never understand that, but M'Wanna M'Bella thinks it's a great thing to say and he rubs his hands in satisfaction. Yes, I'm your little paizinho, he says, while he parades and prances back and forth along the counter holding his glass of beer and stuffing his chest. The four dollar whore isn't even expecting us to go for her, so she's very surprised when M'Wanna M'Bella makes me ask her to go to a room with us. I explain to her it's his first night out and he's getting to be a big, free man of the world and he's just learning to take care of himself. He's learning things, I say, and I wink an eye at her but she doesn't seem to see anything, she's still looking very surprised and she says, all right, with a sigh, so we follow her up to this little room upstairs and I keep looking at her with her spotted legs and fat behind and I don't understand what M'Wanna M'Bella sees in her, but he's very, very happy, making clucking noises with his tongue and all that. At first the woman doesn't see why M'Wanna M'Bella wants me to go up to the room with them, but I explain it to her while he stares at us with his olive eyes wide open almost without breathing, and she doesn't even wait till I finish the explanation. She says, all right, all right, with another sigh.

"See?" M'Wanna M'Bella says walking up the stairs three steps at a time. "She says all right, all right all the time. She's very smart."

"Aren't you smart?" he asks touching her gently, but she doesn't answer at all, she just opens the door to the room and lets us in. It's a very small room that doesn't smell very healthy and I'm a little worried about M'Wanna M'Bella getting his first disease but I figure what the hell there's always a first time, and a man is a man even if he's just M'Wanna M'Bella now. I sit in a small chair near the window and I try to open the window to get a view but it seems to be stuck.

"Opens onto a wall," the woman says. "Nobody ever opens it."

"Sure, sure," I say, and sit down again and light a cigarette and try not to think of the proceedings, which is easy, since I'm drunk anyway.

M'Wanna M'Bella watches as the woman undresses her big gobs of fat, and lifts his hand in the air like he's going to make an announcement.

"What I'm gonna say," he says, "may make you think you should charge me more than four dollars, but I'll take none of that crap."

The woman never stops what she's doing and she never looks at M'Wanna 
M'Bella, who seems to be a little disappointed but he breathes hard and keeps on talking like he had rehearsed it in his mind. I'm a tough man, he says, and if I'm gonna pay you good money I want my money's worth. I'll have you know, he says, I'm gonna have you in the mouth and in the backside and in all kinds of ways and I'm never leaving this room until I'm completely satisfied, and don't give me none of that shit of charging more than what your sign said because I know your kind. The woman doesn't say a thing as she's washing herself in the tin basin and wiping herself and moving around like a very heavy critter and finally lying in bed with a stony face.

"The least you could do," M'Wanna M'Bella says, "is you could smile."

So the woman instantly shows her little grimy teeth in a smile and sits there with her legs astride the bed.

“And sing too," M'Wanna M'Bella says, so the woman rolls her eyes toward the ceiling and she sings I'm a puuuta, I'm a prostituuuta. "Louder," M'Wanna M'Bella says with his eyes looking puzzled. The woman goes, I'm a puuuta, puuta, puuta, I'm a prostituuuta, very loudly, until M'Wanna M'Bella raises his hand and says, I wann spank you. The woman turns over very slowly and offers her fat rump to him and suddenly he doesn't seem to know what to do. You said you wanted to spank her, I say. Well, go ahead, I say, and M'Wanna M'Bella marches to the woman and makes as if he's going to spank her but he gets this idea in his head so he says, "I think," he says, "it's a good and proper thing for you to sing while I'm spanking your bunda," so the woman lifts her head a little and goes, I'm a puta, I'm a prostituta, while she's waiting for M'Wanna M'Bella to spank her. but he never does it and he just stands there looking kinda dumbfounded. Oh well, I say, what the hell are you going to do, we ain't got all night to hear you make speeches.

"What is your name?" M’Wanna M'Bella says to the woman.

"Flor," she says.

"And what are you?" he says.

"I'm a puta," she says and lies there waiting.

"I get my kicks," M'Wanna M'Bella says, "pissing on fat women. So you just lie there while I piss on you."

She doesn't speak and she gets up and picks up a piece of plastic from the top of the basin rack and covers the bed with it and lies down on it again. M'Wanna M'Bella comes close to the bed and makes like he's going to piss on her and he gets purple and doesn't do a thing. He folds some bills he takes out of his pocket and hands them to her very carefully and says to me, let's go. I don't much know what's going on but I follow him anyway. I'm so drunk I can hardly think. We go downstairs to drink some more, and M'Wanna M'Bella is very silent all the time and kinda looking at things from a great distance, so I slap him on his shoulder and say just to break the ice:

"So now you're a man of the world."

"Yes," he says not looking like he heard me. He shakes his head in all directions and looks maybe a little sick, so I say, what's the matter with you.

"Oh, do you really think so?" he says. 
"Do you think so what?" I say.

He starts saying something, but he seems to give up halfway. And I never understand what happens, because he walks over to the bouncer who's yawning in his chair by the door with his coat open. And he pulls out the bouncer's gun, points it to his head and shoots himself dead. 